\title{
EVALUATION OF IRRIGATION LEVELS IN THE CASTOR BEAN (Ricinus communis L.) IN THE BRAZILIAN SEMIARID REGION
}

\author{
Breno Rosa Neves ${ }^{1}$, Marcelo Rocha dos Santos², Sérgio Luiz Rodrigues Donato ${ }^{3}$
}

\begin{abstract}
There has been an increase in the search for forms of renewable energy with lo environmental impacts, of which biodiesel is highlighted. The castor bean (Ricinus communis L.) is a major raw material for the derivation of these biomass-based fuels. Due to the lack of information in literature regarding irrigation in castor bean crops in the semiarid region of Bahia, the aim of this study was to evaluate different irrigation levels on growth and yield of castor beans in the semiarid region of Bahia. The study was conducted in an experimental area of the agricultural sector of the Federal Institute of Education, Science and Technology Campus, Guanambi, Bahia, Brazil. The experiment was setup in a completely randomized design with 4x5 factorial scheme, consisting of four irrigation levels (T1: 100\% ETc, T2: 80\% of ETc, T3: $60 \%$ of ETc and T4: 40\% of ETc, with drip irrigation), five evaluation dates $(65,80,95,110$ and 126 day after sowing) and four replications. The reduction in irrigation did not cause differences in plant height, stem diameter and crown diameter of the castor bean cultivar Paraguaçu. Irrigation at $80 \%$ ETc showed to be more suitable, with increased yield and water use efficiency.
\end{abstract}

Keywords: biodiesel, sustainability, water resources

\section{RESUMO}

\section{AVALIAÇÃO DE LÂMINAS DE IRRIGAÇÃO NA CULTURA DA MAMONA (Ricinus communis L.) EM REGIÃO SEMIÁRIDA}

É crescente a busca por formas de energia renovável e de menor impacto ambiental em que o biodiesel apresenta destaque. A mamona (Ricinus communis L.) é uma das principais matérias-prima para a derivação desses combustíveis de origem vegetal. Com a escassez de informações na literatura a respeito de irrigação na cultura da mamona em região de semiárido baiano, objetivou-se com este trabalho avaliar diferentes lâminas de irrigação no crescimento e produtividade de mamoneira irrigada por gotejamento em região semiárida da Bahia. O trabalho foi desenvolvido numa área experimental do setor de agricultura do Instituto Federal de Educação, Ciência e Tecnologia Baiano, Campus Guanambi. O delineamento experimental foi o inteiramente casualizado em esquema fatorial, quatro lâminas de irrigação, T1, 100\% da ETc, T2, 80\% da ETc, T3, 60\% da ETc e T4, 40 \% da ETc, cinco datas de avaliação, 65, 80, 95,110 , e 126 dias após o plantio, e quatro repetições. . A redução na lâmina de irrigação não ocasionou diferenças na altura da planta, diâmetro do caule e diâmetro da copa para a mamoneira cultivar Paraguaçu. A programação da irrigação com $80 \%$ da ETc seria o mais indicado, com melhor produtividade e eficiência de uso da água.

Palavras-chave: biodiesel, recursos hídricos, sustentabilidade

Recebido para publicação em 16/12/2012. Aprovado em 16/07/2013.

1 - Agronomy student at Instituto Federal Baiano - Campus Guanambi, Bahia. E-mail: brenocumuru@gmail.com

2 - Eng. Agro, Professor D.Sc. Instituto Federal Baiano, Campus Guanambi. E-mail: marcelo.rocha@guanambi.ifbaiano.edu.br

3- Eng. Agro, Professor D.Sc. Instituto Federal Baiano, Campus Guanambi. E-mail: sergiodonatoeaf@yahoo.com.br 


\section{INTRODUTION}

Brazil was once considered the world's largest castor bean producer, however since 1982 that position was lost to India and then China. Currently, Brazil ranks third in production of this oilseed and in harvested area (BARRETO et al., 2010). The State of Bahia is the largest national producer, generating 132,324 tons of this grain in 2005 , corresponding to over $85 \%$ of the national production (SOUZA, 2007).

Castor bean production in adequate conditions produces around $1500 \mathrm{~kg} \mathrm{ha}^{-1}$ in rainfed cultivation, although the national yield average is situated below $500 \mathrm{~kg} \mathrm{ha}^{-1}$ due to the low adoption of suitable technology (DIAS et al., 2006).

Biodiesel is a renewable energy source that is currently being researched at many institutions so as to generate information that enables correct decision making to minimize problems that cause environmental impacts. Researches have indicated that the oil demand for production of less polluting fuels will result in increased application of the crop, and may present an opportunity for development of semiarid regions (BELTRÃO et al., 2004)

The definition of biodiesel adopted on the Law $n^{\circ}$ 11.097, of September 13 $3^{\text {th }}, 2005$ in which biodiesel was introduced into the Brazilian energetic matrix is: "Biodiesel: biofuel derivate of renewable biomass for the use in internal combustion engines with compression ignition, or according to the law, to have another kind of energy that can partially or totally replace fossil fuels". (NR).

The castor bean (Ricinus communis L.) is one of the main plant materials used for obtaining vegetal oil. This cultivation is included in the National Biodiesel Program, making up one renewable energy source to replace oil (BELTRÃO et al., 2009).

The castor bean (Ricinus communis L.) culture assumes a great socioeconomic importance for the Brazilian semiarid region because it is easy to grow and presents satisfactory production under low rainfall, thus providing forms of labor and revenue for small rural producers. Its drought resistance, a characteristic that makes the castor bean an important alternative for the Brazilian semiarid region, contrasts with its extreme soil water saturation sensibility, a condition that significantly hinders plant growth and has effect on the crop yield (DIAS et al., 2006).

Although it is a drought tolerant plant (CARTAXO et al., 2004), Beltrão and Silva (1999) claim that the crop needs rainfall levels between 600 and $700 \mathrm{~mm}$ to obtain a production above 1500 $\mathrm{kg} \mathrm{ha}^{-1}$.

The castor bean is well adapted for the semi arid region by being able to produce well under conditions of low water availability (drought tolerance), but also by not having a critical phase in which the lack of water can cause total production loss (BARRETO et al., 2010). Different from soy bean, sunflower, peanut and other oilseeds, the castor bean is not destined for human consumption, therefore from a social point of view there is no competition on the market (SILVA et al., 2009a). Pires et al. (2004) affirms that discussions on biodiesel have sought to prioritize oilseeds that provide more employment and income to rural areas, especially in regions that are on the margins of economic development process.

Definition of the irrigation level needed for productive sustainability with lower water demand, is considered of fundamental importance especially in semiarid regions, where the water demand is elevated and the availability of this resource is low when compared with the other regions of Brazil.

According to the new delimitation (PEREIRA JUNIOR, 2007), the Brazilian semiarid region presented an average annual rainfall lower than $800 \mathrm{~mm}$ and aridity index of up to 0.5 calculated by the water balance, in the period from 1961 to 1990. However, upon further data analysis it was verified that in the driest years, rainfall was less than 200 mm (ANA, 2012) in this region.

Carvalho Junior et al. (2010) evaluated irrigation levels in the castor bean culture and verified that $75 \%$ of the ETo applied corresponded to the most satisfactory castor bean growth and development at BRS Energy in the edaphoclimatic conditions of Barbalha - Ceará, Brazil.

The Northeast Region presents favorable contributions for castor bean cultivation, however the water resource in many locations is a limiting factor. Due to the lack of information in literature on irrigation of the castor bean culture, the present 
study sought to evaluate the effect of different irrigation levels on the growth, water use efficiency and castor bean yield in the Bahia semiarid region.

\section{MATERIAL AND METHODS}

The work was developed in an experimental area of the agriculture sector belonging to the Education, Science, Technology Federal Institute of Bahia, Campus Guanambi, at latitude of $14^{\circ} 13^{\prime} 33^{\prime}$ 'S, longitude of $42^{\circ} 46^{\prime} 53^{\prime}$ ' W, elevation of $525 \mathrm{~m}$, average annual rainfall of $680 \mathrm{~mm}$ and average annual temperature of $25.6{ }^{\circ} \mathrm{C}$, in a Oxisol of medium texture composed of $0.590 \mathrm{~kg} \mathrm{~kg}^{-1}$ sand, $0.195 \mathrm{~kg} \mathrm{~kg}^{-1}$ silt and $0.215 \mathrm{~kg} \mathrm{~kg}^{-1}$ clay, with bulk density of $1.66 \mathrm{~kg} \mathrm{dm}^{-3}$.

The study had was performed using different irrigation levels in the castor bean 'Paraguaçu' culture since the sowing, on July $27^{\text {th }} 2011$, to the harvest on November $15^{\text {th }}$ 2011. Plants were spaced at $1,5 \mathrm{~m}$ and rows spaced at $2 \mathrm{~m}$, irrigated by drip irrigation with flow rate per plant of $8 \mathrm{~L} \mathrm{~h}^{-1}$.

The experiment was setup in a completely randomized design with $4 \times 5$ factorial scheme and four replications, representing the experimental plot consisting of four rows with five plants per row. In the experimental plot the three central plants of the two central rows were used.

The treatments included: four irrigation levels, T1: $100 \%$ ETc, T2: $80 \%$ of ETc, T3: $60 \%$ of ETc and T4: $40 \%$ of ETc and five evaluation dates: 65, 80, 95, 110 and 126 days after sowing (DAS). Different irrigation levels applied by drip irrigation were obtained by varying the time of application through the closing of the regulators for the different treatments. Irrigations values were based on the reference crop evapotranspiration (ETo) determined daily via the Penman-Monteith method (Eq. 1) (FAO standard-method) (ALLEN et al., 1998), calculated from weather data gathered at a standard meteorological station installed approximately $200 \mathrm{~m}$ from the area. The crop coefficients (Kc) used in the evapotranspiration calculation during the castor bean cycle were of 0.35 in the initial phase from sowing to 50 days after the sowing (DAS); 0.75 on the growing phase, between 51 to 87 DAS, and 1.05 for the intermediate and final periods, after 88 DAS, according to Doorenbos and Pruitt (1977).

$$
\text { ETo }=\frac{0.408 \Delta .40-\mathrm{G})+\gamma \frac{900}{\mathrm{~T}+273} \mathrm{U}_{2}\left(\mathrm{e}_{\mathrm{s}}-\mathrm{e}_{\mathrm{a}}\right)}{\Delta+\gamma\left(1+0.34 \mathrm{U}_{2}\right)}
$$

where,

$\mathrm{Rn}$ and $\mathrm{G}=$ daily net radiation and soil heat flux in MJ $\mathrm{m}^{-2}$, respectively;

$\gamma=$ psychometric constant $\left(\mathrm{kPa}^{\circ} \mathrm{C}^{-1}\right)$;

$\Delta=$ the slope of the saturation vapor pressure curve $\left(\mathrm{kPa}{ }^{\circ} \mathrm{C}^{-1}\right)$;

$\mathrm{T}=$ average temperature $\left({ }^{\circ} \mathrm{C}\right)$;

(es - ea) $=$ vapor pressure deficit $(\mathrm{kPa})$; and,

$\mathrm{U} 2=$ mean daily wind speed $\left(\mathrm{m} \mathrm{s}^{-1}\right)$ at $2 \mathrm{~m}$ above soil surface.

Crop evapotranspiration (ETc) for management purposes in the different treatments was calculated according to Equation 2.

$\mathrm{ETc}=\mathrm{ETo} \mathrm{Kc} \mathrm{K1}$

where,

$\mathrm{ETo}=$ reference crop evapotranspiration $\left(\mathrm{mm} \mathrm{d}^{-1}\right)$; $\mathrm{Kc}=$ crop coefficient (dimensionless); and, $\mathrm{K} 1=$ location coefficient (dimensionless).

The irrigation time per day, based on irrigation management during the experiment, was calculated using the equation recommended by Goodwin and Boland (2000) and supplemented with the application efficiency, as shown in Equation 3.

$$
\mathrm{Ti}=\frac{\mathrm{ETc} \times \mathrm{Rp} \times \mathrm{E}_{1} \times \mathrm{E}_{2}}{\mathrm{q} \times \mathrm{n} \times \mathrm{Ea}}
$$

where,

$\mathrm{Ti}=$ irrigation time $\left(\mathrm{h} \mathrm{d}^{-1}\right)$;

$\mathrm{Rp}=\mathrm{ETc}$ replacement according to the treatment (decimal);

$\mathrm{E}_{1}=$ space between plant rows $(\mathrm{m})$;

$\mathrm{E}_{2}=$ space between plants in the row (m);

$\mathrm{q}=$ drip flow rate $\left(\mathrm{L} \mathrm{h}^{-1}\right)$;

$\mathrm{n}=$ number of emitters per plant; and,

$\mathrm{Ea}=$ application efficiency (decimal).

The water used in irrigation, with average electrical conductivity of $0.62 \mathrm{dS} \mathrm{m}^{-1}$, was acquired from 
tubular wells. In rainfall occurrences, this quantity was subtracted from the ETc to obtain the irrigation time. The total irrigation applied during the evaluation period was $392.41,312.07,231.65$ and $151.48 \mathrm{~mm}$ for the $100,80,60$ and $40 \%$ of ETc, respectively.

The location coefficient values (K1) were calculated considering the area shaded by the plant or the area wetted by the irrigation system, were according to Bernardo et al. (2006) the largest values prevailed, obtaining a unitary value.

The principal climate variables that directly influence the reference crop evapotranspiration, and consequently the crop evapotranspiration, are verified in Figure 1.

During the experiment implementation period, growth evaluation was performed fortnightly, including plant height, stem diameter, crown diameter in the different treatments, making direct measurements with a measuring tape and caliper rule. At the moment of harvest the number of bunch per plant was quantified, followed by evaluating yield in the different treatments.

Because of the high rainfall that occurred 111 days after sowing, this day was selected to end the evaluation process. Intense rainfall for prolonged periods (Figure 1) could possibly contribute to unexpected development and production of the culture according to the objective and methodology of the work.

The data obtained for plant height, stem diameter, crown diameter, yield and water use efficiency (WUE) was submitted to analysis of variance and regression.

Water use efficiency (WUE), in $\mathrm{kg} \mathrm{ha}^{-1} \mathrm{~mm}^{-1}$, of the castor bean was obtained according to equation 4 (SILVA et al., 2009b).
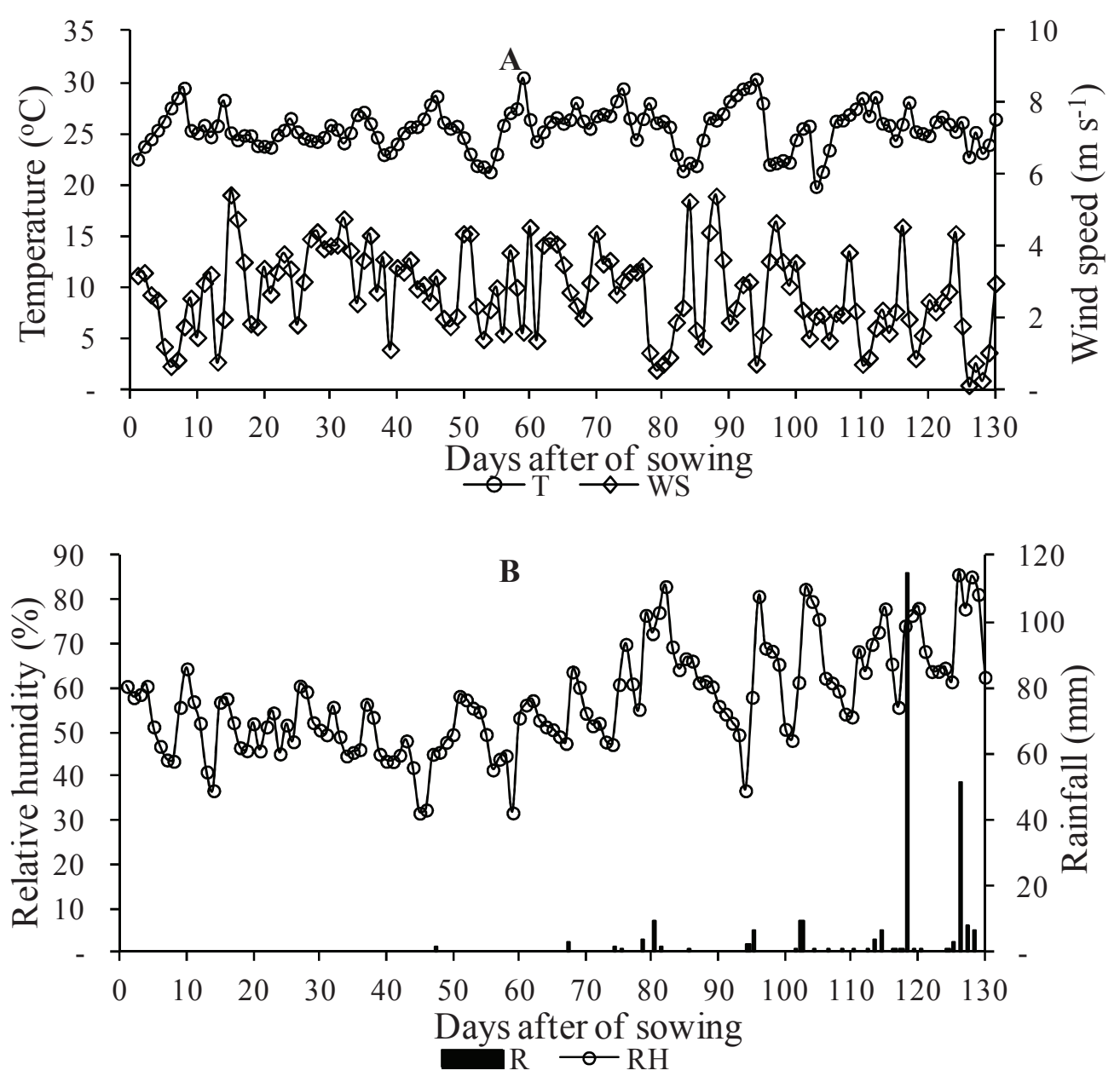

Figure 1. Average temperature - $\mathrm{T}$ and wind speed at two meters high -WS (A) and average relative humidity - RH and rainfall - R (B) per day during the evaluation cycle in Ceraima, Guanambi - Bahia, Brazil. 


$$
\mathrm{WUE}=\frac{\mathrm{Y}}{\mathrm{I}}
$$

where,

$\mathrm{Y}=$ castor bean yield $\left(\mathrm{kg} \mathrm{ha}^{-1}\right)$; and, $\mathrm{I}=$ irrigation applied (mm).

\section{RESULTS AND DISCUSSION}

The parameters of plant height, crown diameter, and stem diameter of the castor bean in different determinations in the plant development, are verified in Figure 2, Figure 3 and Figure 4, respectively. There was no interaction between irrigation levels and evaluation periods for plant height, crown diameter and stem diameter, indicating that the reduction of the irrigation level to $40 \%$ of its water necessity does not interfere in plant development. There were differences between the evaluation periods for plant height, crown diameter and stem diameter (Figure 2 to 4), regardless of irrigation levels used, and also between yields for irrigation levels (Figure 5) and water use efficiency (Figure 6), regardless of the evaluation time.

Quadratic regression models were fitted to estimate plant height, crown diameter and stem diameter (Figure 2, 3 and 4).

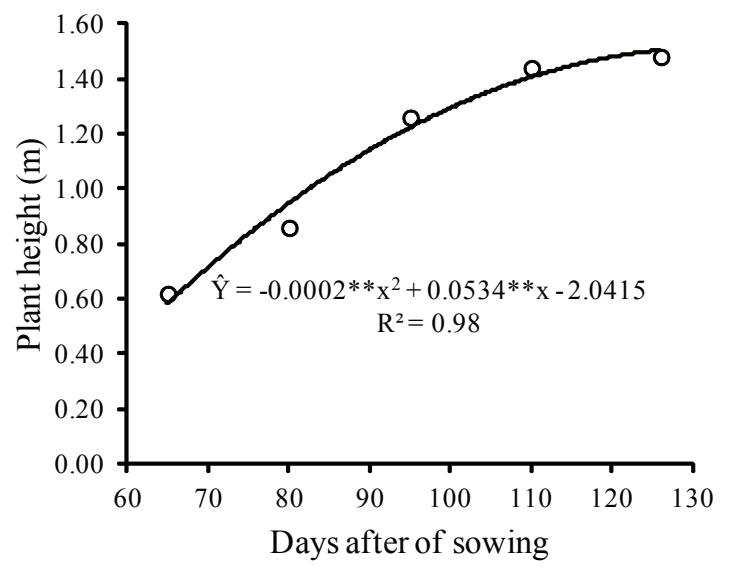

Figure 2. Regression model to estimate the plant height at differents stages of crop development under differents irrigation levels in Ceraima, Guanambi - Bahia, Brazil.

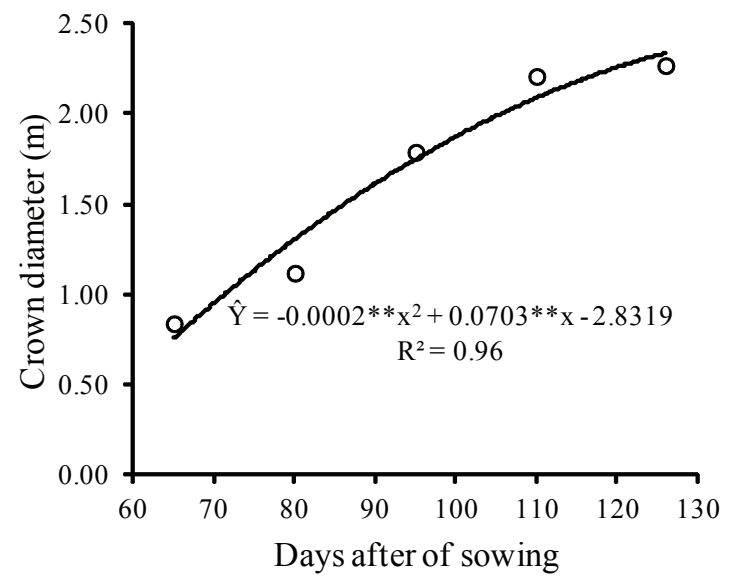

Figure 3. Regression model to estimate the crown diameter in differents stages of crop development under differents irrigation levels in Ceraima, Guanambi - Bahia, Brazil.

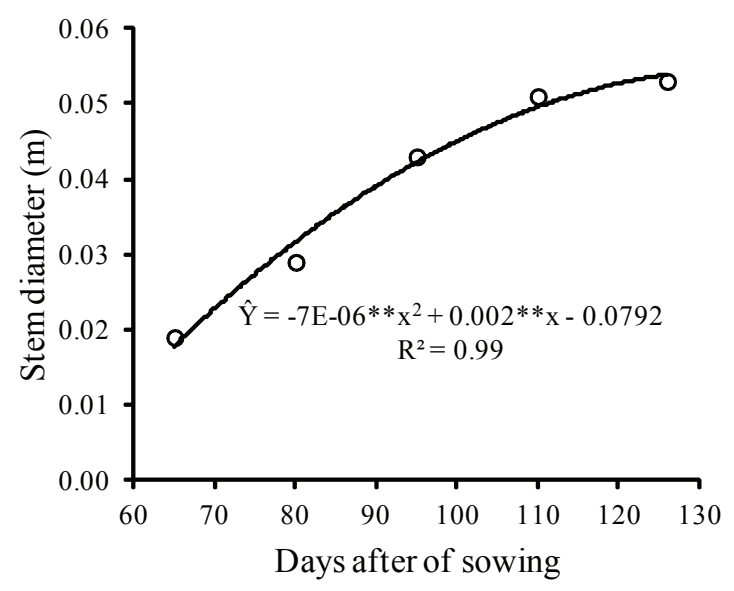

Figure 4. Regression model to estimate the stem diameter in differents stages of crop development under differents irrigation levels in Ceraima, Guanambi - Bahia, Brazil.

Yield and water use efficiency (WUE) of the castor bean 'Paraguaçu' was influenced by the different irrigation levels adopted, different from the plant height, stem diameter and crown diameter. In the Figure 5 it is verified that the irrigation level of $80 \%$ Etc resulted in the best yield. The adjusted quadratic regression model estimated higher castor bean yields of $2272 \mathrm{~kg} \mathrm{ha}^{-1}$ for the irrigation depth with $78 \%$ of crop evapotranspiration. 


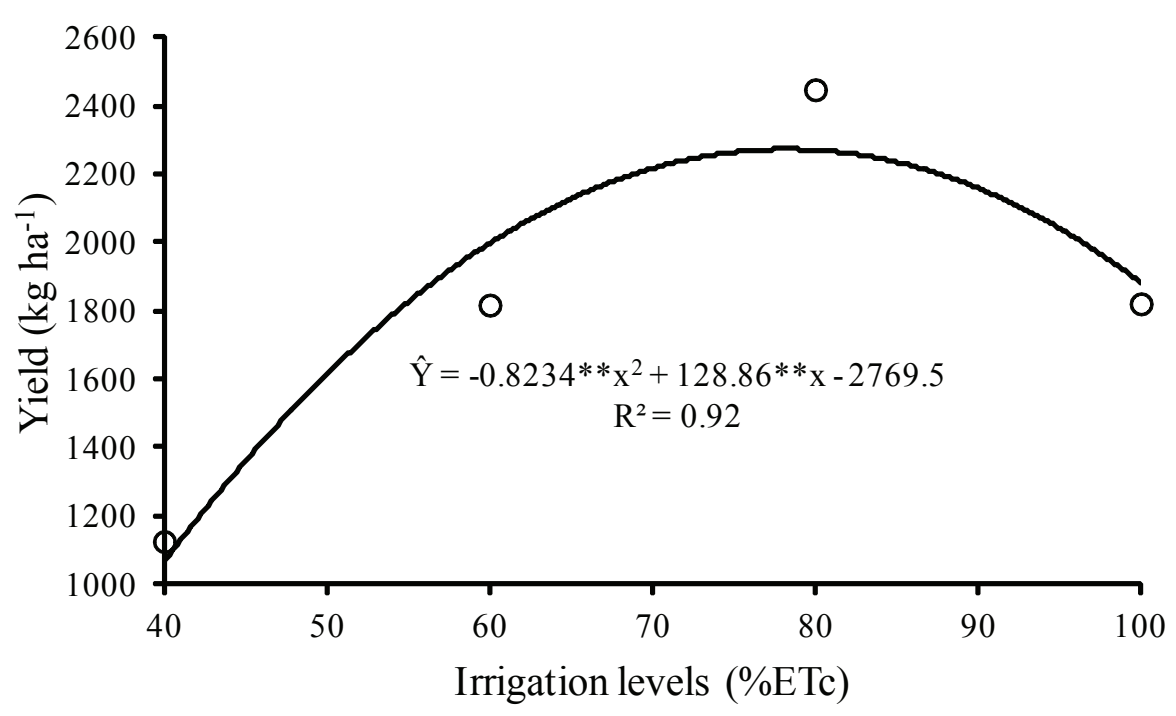

Figure 5. Regression model to estimate the yield of the castor bean 'Paraguaçu' under different irrigation levels in Ceraima, Guanambi - Bahia, Brazil.

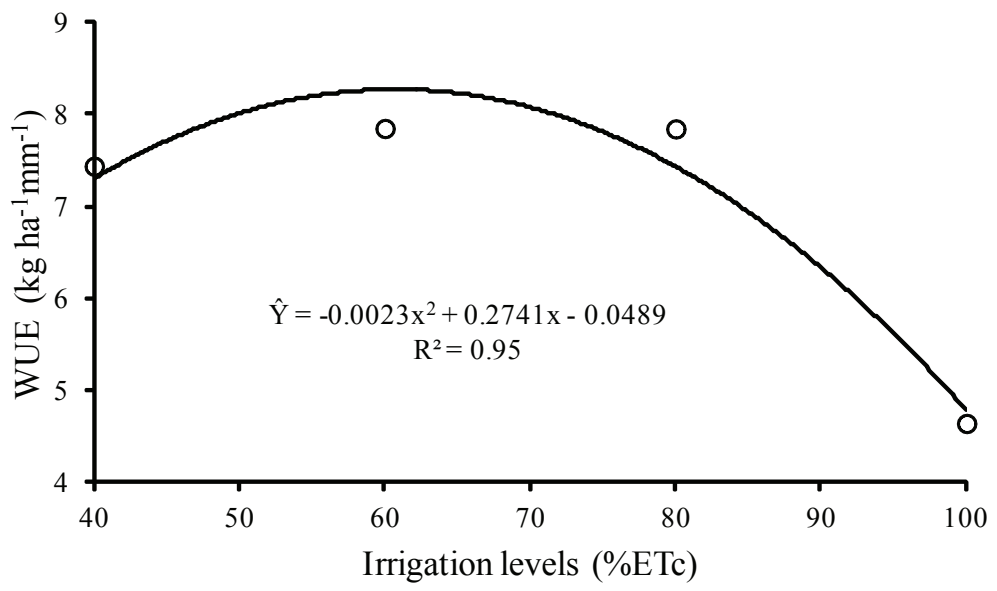

Figure 6. Regression model to estimate the water use efficiency (WUE) of the castor bean 'Paraguaçu' under differents irrigation levels in Ceraima, Guanambi - Bahia, Brazil.

Biscaro et al. (2012), in his work with different irrigation levels in two castor bean species, highlighted that the increased irrigation level resulted in a significant development of almost all the production components and culture yield, and the plants that presented the highest yield received $150 \%$ of the ETc. The results of yield found in the present study differ from those found by Biscaro et al. (2012), which can be related to inherent factors of the variety and edaphoclimatic conditions.

The results of this study corroborate with those of Carvalho Junior et al. (2010) who evaluated irrigation levels in the castor bean culture, where it was verified that $75 \%$ of the ETo applied corresponded to the most satisfactory level for growth and development of the castor bean BRS Energy in the edaphoclimatic conditions of Barbalha, Ceará. This diverges from the results of Beltrão and Silva (1999) who reported that the culture requires between 600 and $700 \mathrm{~mm}$ of rainfall to obtain a yield greater than $1500 \mathrm{~kg} \mathrm{ha}^{-}$ ${ }^{1}$. In this work, with irrigation and rainfall slightly greater than $300 \mathrm{~mm}$, a yield of about $2450 \mathrm{~kg} \mathrm{ha}^{-1}$ was obtained.

Regarding water use efficiency, the model estimates the best WUE for the irrigation depth 
with $60 \%$ of crop evapotranspiration (Figure 6). The water use efficiency related the ecological yield or fruit yield with water consumption/ evapotranspiration (SOUSA et al., 2008). The present work corroborated with that of Sousa et al. (2008) with respect to the efficiency values reported for the levels applied, presenting the highest efficiency values for lower levels of the ETc; however in this work Sousa et al. (2008) found the most satisfactory WUE when supplying $60 \%$ of the ETc. Both works diverged from that of Junior et al. (2008), who when working with the cultivars Nordestina and Paraguaçu, presented an increasing pattern in the WUE values relative to water availability, with the lowest values of efficiency encountered for less water availability.

In irrigated conditions of the semiarid region of Bahia and from the view of sustainable water used, irrigation management in the castor bean 'Paraguaçu' can be performed at $80 \%$ of the ETc, since this irrigation level resulted in the most satisfactory water use efficiency and yield.

\section{CONCLUSIONS}

- The reduction in irrigation level does not cause differences in plant height, crown diameter, and stem diameter for the castor bean 'Paraguaçu' cultivated in the semiarid region of Bahia;

- Irrigation of the castor bean 'Paraguaçu' can be performed at $80 \%$ of the ETc in the semiarid region of Bahia.

\section{REFERENCES}

ANA. Agência Nacional de Águas. Abailable at: http://hidroweb.ana.gov.br/HidroWeb.asp?Toc Item $=1080 \&$ TipoReg $=7 \&$ MostraCon $=$ false \&Cria Arq $=$ false $\&$ TipoArq $=1 \&$ SerieHist $=$ true $>$. Access in: 11 mar. 2012.

ALLEN, R.G.; PEREIRA, L.S.; RAES, D.; SMITH, M. Crop evapotranspiration: guidelines for computing crop water requirements. Irrigation and Dranaige Paper, 56. FAO: Rome. 1998. 300p.

BARRETO, H.B.F.; MEDEIROS, J.F.; MAIA,
P.M.E.; COSTA, E.M.; OLIVEIRA, L.A.A. Avaliação do crescimento de acessos de mamona cultivada sob irrigação na região de Mossoró-RNBrasil. Revista Verde, Mossoró, v.5, n.2, p.185193, 2010.

BERNARDO, S.; SOARES, A.A.; MANTOVANI, E.C.. Manual de Irrigação. 8. ed. Viçosa: Editora UFV, 2006. 625p.

BELTRÃO, N.E.M.; OLIVEIRA, M.I.P.; AMORIM, M.L.C.M. Opções para a produção de biodiesel no semiárido brasileiro em regime de sequeiro: porque algodão e mamona. Campina Grande: Embrapa Algodão (Documentos, 220). 2009. 36p.

BELTRÃO, N.E.M.; ROCHA, P.; MOTA, J.R.; SEVERINO, L.S.; CARDOSO, G.D.; SILVA, G.A.; QUEIROZ, U.C. Segmentos do agronegócio da mamona. I. Diagnóstico da ricinocultura da região de Irecê, estado da Bahia. I Congresso Brasileiro da Mamona. Anais. Embrapa Algodão. Campina Grande, 2004.

BELTRÃO, N.E.M.; SILVA, L.C. Os múltiplos usos do óleo da mamona (Ricinus communis L.) e a sua importância do seu cultivo no Brasil. Fibras e óleos, Campina Grande, n.31, p.7, 1999.

BISCARO, G.A.; VAZ, M.A.B.; GIACON, G.M.; GOMES, E.P.; SILVA, S.B.; MOTOMIYA, A.V.A. Produtividade de duas cultivares de mamona submetida a diferentes lâminas de irrigação suplementar. Campina Grande, PB: Revista Brasileira de Engenharia agrícola e Ambiental, Campina Grande, v.16, n.9, p.925-930, 2012.

CARTAXO, W.V.; BELTRÃO, N.E.M.; SILVA, O.R.R.F.; SEVERINO, L.S.; SUASSUNA, N.D.; SOARES, J.J. O cultivo da mamoneira no semiárido brasileiro. Campina Grande: Embrapa Algodão (Circular Técnica, 77). 2004. 20p.

CARVALHO JÚNIOR, G.S.; PEREIRA, J.R.; QUESADO, F.C.; CASTRO, M.A.N.; SOUZA, D.F.; ABDALA, C.S.; ARAÚJO, W.P.; LIMA, F.V. Comportamento da mamoneira BRS energia em diferentes lâminas de irrigação. In. Congresso 
Brasileiro de Mamona e I Simpósio Internacional de Oleaginosas Energéticas, 4., João Pessoa, PB. Anais... João Pessoa, PB. 2010.

DOORENBOS, J.; PRUITT, J.O. Crop water requeriment. (FAO Irrigation and Drainage Paper 24). Rome: FAO, 1977. 144p.

DIAS, J.M.; SILVA, S.M.S.; GONDIM, T.M.S.; SEVERINO, L.S.; BELTRÃO, N.E.M.; BEZERRA, J.R.C.; VASCONCELOS, R.A.; Efeitos de diferentes quantidades de água de irrigação e de densidades populacionais na cultura da mamona. Congresso Brasileiro de mamona, 2., Aracaju, SE. 2006.

GOODWIN, I.; BOLAND, A.M. Scheduling deficit irrigation of fruit trees for optimizing water use efficiency In. Deficit Irrigation Practices, Water Reports, Roma, FAO, n.22, p.67-78, 2000.

JUNIOR,G.B.;GUERRA,H.O.C.;CAVALCANTI, M.F.; LACERDA, R.D.; Consumo de água e eficiência do uso para duas cultivares de mamona submetidas a estresse hídrico. Revista Brasileira de Engenharia Agrícola e Ambiental, Campina Grande, v.12, n.4, p.350-355, 2008.

PEREIRA JUNIOR, J.S. Nova delimitação do semi-árido brasileiro. Biblioteca Digital da Câmera dos Deputados. Centro de Documentação e Informação. Brasília, DF. 2007. 24p.
PIRES, M.M.; ALVES, J.M.; ALMEIDA NETO, J.A.; ALMEIDA, C.M.; SOUSA, G.S.; CRUZ, R.S.; MONTEIRO, R.; LOPES, B.S.; ROBRA S. Biodiesel de mamona: Uma avaliação econômica. In: Congresso Brasileiro da Mamona, 1., Anais. Embrapa Algodão. Campina Grande, 2004.

SOUSA, P.S.; FILHO, F.Q.P.; MEDEIROS, J.F.; MESQUITA, T.O.; OLIVEIRA, C.J.S.; NETO, A.J.A.; DIAS, A.F.S. Eficiência do uso da água pela mamoneira sob diferentes lâminas de irrigação. In: Congresso Brasileiro de Mamona, 3., Anais. SEAGRI/EMBRAPA, Salvador, BA. 2008.

SOUZA, A.S. Manejo cultural da mamoneira: época de plantio, irrigação, espaçamento e competição de cultivares. 2007. 211f. Tese (Doutorado em Agronomia) - Universidade Federal do Ceará, Fortaleza. 2007.

SILVA, S.M.S.; GHEYI, H.R.; BELTRÃO, N.E.M.; SANTOS， J.W.; SOARES， F.A.L. Dotações hídricas em densidades de plantas na cultura da mamoneira cv. BRS Energia. Revista Brasileira de Ciências Agrárias, Recife, v.4, n.3, p.338-348, 2009a.

SILVA, V.P.R.; CAMPOS, J.H.B.C.; AZEVEDO, P.V. Water-use efficiency and evapotranspiration of mango orchard grown in northeastern region of Brazil. Scientia Horticulturae, Netherlands, v.120, p. 467-472, 2009 b. 